\title{
Crucial problems in arranged the lesson plan of vocational teacher
}

\author{
Muhammad Nurtanto ${ }^{1}$, Nur Kholifah ${ }^{2}$, Alias Masek ${ }^{3}$, Putu Sudira ${ }^{4}$, Achmad Samsudin ${ }^{5}$ \\ ${ }^{1}$ Department of Mechanical Engineering Education, Faculty of Teacher Training and Education, Universitas Sultan \\ Ageng Tirtayasa, Indonesia \\ ${ }^{2}$ Department of Fashion Design and Hospitality Education, Faculty of Engineering, Universitas Negeri Yogyakarta, \\ Yogyakarta, Indonesia \\ ${ }^{3}$ Professional Education and Postgraduate Department, Faculty of Technical and Vocational Education, Universiti Tun \\ Hussein Onn Malaysia, Malaysia \\ ${ }^{4}$ Department of Postgraduate, Technical and Vocational Education, Universitas Negeri Yogyakarta, Indonesia \\ ${ }^{5}$ Department of Physics Education, Universitas Pendidikan Indonesia, Bandung, Indonesia
}

\section{Article Info \\ Article history: \\ Received Mar 24, 2020 \\ Revised Nov 13, 2020 \\ Accepted Jan 27, 2021}

\section{Keywords:}

Curriculum

ICT

Learning tools

Lesson plan

Vocational teachers

\begin{abstract}
This study aimed to explore the implementation of the 2013 curriculum in vocational schools, Banten in terms of the readiness and quality of the learning tools that have been prepared. A total of 957 respondents from 2017 to 2018, consisting of four cities and three districts in Banten Province were involved in the training and mentoring program, namely vocational teachers and vice-principals in the curriculum field. Data were collected using questionnaire sheets, FGD notes, and observation check dates. The data obtained are analyzed and interpreted based on the specified categories. The results showed that: 1) Teacher readiness for learning tools in the components a) Core Competencies (CC) and Basic Competencies (BC) analysis of $45.31 \%$, b) Program mapping of $38.37 \%$, learning plan preparation of $39.45 \%$ and c) Learning evaluation of $36.78 \%$; 2) The quality of lesson plan (LP) the science lesson plan analysis instrument (SLPAI) based is divided into two groups. The category "Quality" in the instructional program and instructional plan aspects, and the category "Moderate" in the instructional media and assessment and others aspects; and 3) The difficulty of learning device components, including authentic assessment, use of methods, literacy approaches, and lesson planning. The implementation of training, mentoring, and supervision programs are adjusted to the experience of vocational teachers taking into account the teacher's involvement in the implementation of the curriculum, age, and school readiness.
\end{abstract}

This is an open access article under the CC BY-SA license.

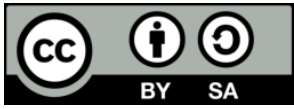

\section{Corresponding Author:}

Muhammad Nurtanto

Department of Mechanical Engineering Education

Faculty of Teacher Training and Education

Universitas Sultan Ageng Tirtayasa

Kota Serang, Banten 42124, Indonesia

Email: mnurtanto23@untirta.ac.id

\section{INTRODUCTION}

The curriculum will change continuously [1, 2], according to the needs and challenges of globalization [3, 4]. The Indonesian government has replaced the 2006 curriculum called the Education Unit Level Curriculum (KTSP) into the 2013 curriculum known as the national curriculum [5-7]. The 2013 
curriculum was first implemented in 2013. Significant changes lie in three separate competency standards in the assessment process, namely knowledge, skills and attitude competencies. The implementation of the 2013 curriculum involved 6,000 schools as a reference school model and six schools at the district level. The implementation process consists of several stages, including training from the national level, instructor training, and training from referral schools that are intended to have the same understanding. However, many factors cause perception differences to occur after the implementation process. The main target of the training is the teacher as the main actor of the 2013 curriculum practitioners in the education unit. Other targets are school leaders and supervisors who are part of the curriculum management, management team [8].

Planning that was not well prepared for the implementation of the 2013 curriculum, it was evident in December 2014 that a decision emerged from the government that the re-enactment of the 2006 curriculum (KTSP) and schools that held the 2013 curriculum running for one semester had to be stopped [9, 10]. However, for schools that have three semesters, schools can choose to continue implementing the 2013 curriculum. The main reason for the emergence of this decision is the change of the system and the increase in administrative tasks of teachers, especially more on the concept of devices that require the role of the teacher more than just teaching. In addition, teachers are preoccupied with rigorous preparation in student assessment. In fact, the government believes that the 2013 curriculum provides a significant change in the quality of learning. Therefore, several alternative improvements and preparatory efforts for implementation have been analyzed [11, 12]. Furthermore, in 2017 the Directorate General of Primary and Secondary Education Decree No. 253.KEP/D/KR/2017 to re-establish the 2013 curriculum independently with the decision of the Directorate General of Primary and Secondary Education No. 335/Kep./D/KR/2017. The decision became the basis that the 2013 curriculum was implemented nationally. Some refinements from the 2013 curriculum have been made, namely flexible and moderate content and implementation. The purpose of re-enacting the 2013 curriculum is due to growing demand, needs and conditions from the aspect of society in educational output [13].

The key to the success of the quality of education is not limited to curriculum changes, but rather the readiness and understanding of teachers in carrying out curriculum content $[14,15]$. However, the good curriculum is, if the teacher's mindset is not changed $[16,17]$, then the curriculum cannot be meaningful. In addition, the characteristics of teachers as curriculum practitioners are influenced by the length of time teachers are involved in the curriculum and high awareness in improving the quality of learning. Some obstacles in implementing the 2013 curriculum from the practitioner's point of view include the implementation of an assessment system [18], limited teacher and student handbooks [19], mental readiness of teachers and students that are not optimal, and not all schools are involved in implementing the 2013 curriculum [20]. These obstacles are more on administrative planning, namely the teacher's ability to plan learning programs and compile them into lesson plans [7, 20].

Preparation of semester learning programs and annual learning programs that are translated into learning plans is not an easy problem [21, 22]. Teachers can map and share competencies for one year and one semester comprehensively without harming other competencies. The teacher can read the national academic calendar and the school academic calendar, then replace it with a learning program preparation strategy. The content of competencies that are not the same is a special consideration in the preparation of learning programs. In addition, vocational teachers who are scheduled on the day, which are often found on holiday days, must have a good strategy. The lack of teachers in breaking the curriculum into a semester and annual learning programs makes learning ineffective, which results in students being disadvantaged by a number of incomplete competencies.

Calculation of effective weeks distributed from Core Competencies and Basic Competencies (CC/BC) refers to government regulation No. 330/D.D5/KEP/KR/2017, adjusted to the subjects that will be distributed in the learning program for one year. Vocational teachers need a strategy for the distribution of $\mathrm{CC}$ and $\mathrm{BC}$ into learning programs. Complex competencies need to be considered that the number of meetings needs to be added. Learning programs are considered good if the number of hours in a matter of weeks is effective to or close to the number of hours in the curriculum spectrum. The learning program becomes a basic guideline for teachers in preparing learning plans. The basis for preparing a learning plan has been systematically arranged in the development of a lesson plan.

The successful implementation of learning is due to effective planning. Benchmark of learning success is the achievement of learning objectives. The learning plan is interpreted as a teacher's guide during the learning process $[4,23]$, so that the learning scenario cannot be separated from the context that has been prepared [24, 25]. It often happens that the teacher during the learning process loses context [26, 27], far from the discussion, even the accuracy of the time is not quite right. This is why learning plans are arranged to achieve learning objectives. However, the learning plan is administrative in nature, whereas in actual circumstances the teacher must be able to consider the contents of the material, the method chosen, the activities to be carried out, the implementation of the practice, and the class mastery strategy must be 
interrelated and complementary [28]. Teachers during the learning process who do not use learning tools or lesson plan often experience getting lost or losing direction [29].

The preparation of learning tools is a core competency that must be possessed by teachers, namely pedagogical competence [30,31]. Preparation of learning plans is not easy, many factors must be considered such as curriculum characteristics, student characteristics, and the availability of learning support materials. Teacher pedagogic competencies [32-34], consisting of: 1) Mastery of student characteristics (teachers must understand students' personalities); 2) Designing learning; 3) Carry out learning; 4) Utilizing ICT; 5) Design and carry out an evaluation of the process and learning outcomes. Learning planning is the preparation stage and part of pedagogical competence that must be compiled by the teacher before performing in front of the class or in the workshop.

The new curriculum has specific characteristics or reinforcement. The characteristics of the 2013 curriculum as a national curriculum focuses on the digitization approach, including the use of ICT-based media and literacy, scientific learning methods, assessment methods include three aspects, namely knowledge, skills, and attitudes, as a whole are packaged in learning planning. The unique characteristics of the 2013 curriculum are learning activities using the 5M or (OACAC) approach, namely: Observing (M1/O), Asking (M2/A), Collecting information (M3/C), Associating/Reasoning (M4/A), Communicating (M5/C) $[35,36]$.

If the meaning of the OACAC activity is the phase of the scientific model or method applied in learning. The OACAC activity is believed to be able to create the nuances of learning to be active [37]. Unconsciously the components in preparing a lesson plan are very complex and detailed. Many teachers choose the short cut by copying documents from their fellow teachers. As a result, the teacher has difficulty understanding, interpreting and implementing the learning plan. Other conditions, a number of teachers copied several sources, but adjusted back to the characteristics of students and their learning environment [11]. To improve the quality of learning and pedagogy competence of teachers can be observed from the lesson plans that have been prepared and developed.

This study uses a survey approach to see the quality of teacher lesson planning in Banten Province. This study provides information on vocational teacher ready and mastery of the revised 2013 curriculum in the distribution of learning programs and lesson plans, so that the contribution of this research is a recommendation of teacher needs that must be improved in vocational secondary schools. Implementation of the curriculum must be assessed objectively, regularly from various perspectives [38], to improve the quality of learning. Furthermore, this research is used as a reference for teachers, principals, supervisors, education department, and practitioners, as material to improve the quality of vocational education, especially the readiness of good learning tools.

\section{RESEARCH METHOD}

This research is a survey and Focus Group Discussion (FGD) study to describe the vocational teacher learning tools before performing performance in class. The survey method uses a design developed by Rea and Parker [39]. Data was collected from observation of the activities of vocational teachers through training and assistance in the preparation of learning tools consisting of learning programs and lesson planning based on the 2013 curriculum from 2017 to 2018. The research sample consisted of seven districts in Banten namely Serang City, Serang District, Cilegon City, Pandeglang Regency, Lebak Regency, South Tangerang City, and Tangerang City. All Vocational teachers who participated in the study, representatives from vocational schools in each district were taken as research samples. The research subjects are presented in Table 1.

Table 1. Respondent demographic data

\begin{tabular}{clcc}
\hline No & Distribution of respondents & F & $(\%)$ \\
\hline 1 & Serang City & 90 & 9.40 \\
2 & Serang Regency & 125 & 13.06 \\
3 & Cilegon City & 88 & 9.20 \\
4 & Pandeglang Regency & 115 & 12.02 \\
5 & Lebak Regency & 200 & 20.90 \\
6 & South Tangerang City & 200 & 20.90 \\
7 & Tangerang City & 139 & 14.52 \\
& Total respondents & 957 & 100.00 \\
\hline
\end{tabular}


Respondents are representatives of vocational schools that have an important role as curriculum actors (vocational teachers and vice-principals in the field of curriculum). The researcher analyzed the respondents involved consisting of the characteristics of the curriculum implemented, namely the 2004 competency-based curriculum, the 2006 teacher-level curriculum, and the 2013 revised curriculum. Problems faced by vocational teachers will be carried out with the three cases above. Research procedures include surveys, FGD results and observations. The survey instrument uses questions that are grouped with polytomy variables.

The research instrument was in the form of questionnaires and FGD notes and observation sheets. The instrument was referred from the Directorate of Vocational High School Development Manager for the purpose of assessing the lesson plan. FGD notes aim to classify the problems that occur and are experienced by practitioners, observation sheets are used to observe the training process and the assistance of vocational teachers. The instrument is equipped with a rubric to measure the quality of the lesson plan.

The collected data is analyzed quantitatively and qualitatively. Vocational teacher readiness in preparing learning devices is categorized into three groups, namely Ready (R); less ready (LR); and not ready (NR). The quality of the learning plan is adopted and adjusted from the science lesson plan analysis instrument (SLPAI) developed by Jacobs, Martin, and Otieno [40], as many as four variables, namely instructional program, instruction plans, instructional media, and assessment and other aspects with five decision assessments namely VHQ (very high quality); Q (quality); M (moderate); LQ (low quality); and VLQ (very low quality) [41]. Table 2 shows the readiness and quality variables of the learning tools as well as the lesson plans compiled by vocational teachers based on the 2013 curriculum.

Table 2. Indicators of readiness and quality of vocational teacher learning tools for the revised 2013

\begin{tabular}{clccll}
\multicolumn{5}{c}{ curriculum } \\
\hline \multirow{2}{*}{ No } & Variable readiness arranging learning & Catg. & No & $\begin{array}{c}\text { Variable quality of } \\
\text { learning plan }\end{array}$ & \multicolumn{1}{c}{ Catg. } \\
\hline 1 & CC and BC analysis & & 1 & Instructional program & $86-100 \%(\mathrm{VHQ})$ \\
2 & Annual and semester program mapping & & 2 & Instructional plan & $71-85 \%$ (Q) \\
3 & Making of lesson plans & R/LR/NR & 3 & Instructional media & $56-70 \%(\mathrm{M})$ \\
4 & Learning evaluation & & 4 & Assessment and others & $41-55 \%$ (LQ) \\
& & & & $<40 \%$ (VLQ) Adapted from [41] \\
\hline
\end{tabular}

Note: R=Ready; LR=Less Ready; NR=Not Ready; VHQ=Very High Quality; Q=Quality; M=Moderate; LQ=Low Quality; and VLQ=Very Low Quality

\section{RESULTS AND ANALYSIS}

\subsection{Teachers readiness for compiling learning tools}

The implementation of the 2013 curriculum does not yet have a uniform understanding between vocational teachers, curriculum practitioners and vocational school leaders. Even through MGMP (Deliberation of Subject Teachers), there is still no uniformity. Researchers examine the readiness of vocational teachers based on $\mathrm{CC}$ and $\mathrm{BC}$ analysis, program mapping, making of lesson plans, and learning evaluation, as the main components in supporting learning success. The results of vocational teacher readiness for the preparation of learning tools are presented in Table 3.

Table 3. Teacher's comprehension about revision 2013 curriculum

\begin{tabular}{lccc}
\hline \multicolumn{1}{c}{ Aspects of teacher readiness } & $\mathrm{R}(\%)$ & $\mathrm{LR}(\%)$ & $\mathrm{NR}(\%)$ \\
\hline CC and BC analysis & $434(45.31)$ & $396(41.39)$ & $127(13.3)$ \\
Annual and semester program mapping & $367(38.37)$ & $343(35.89)$ & $246(25.74)$ \\
Making of lesson plans & $378(39.45)$ & $489(51.07)$ & $91(9.48)$ \\
Learning evaluation & $352(36.78)$ & $483(50.51)$ & $122(12.71)$ \\
\hline Note: R=Ready; LR=Less Ready; and NR=Not Ready & &
\end{tabular}

Table 3 describes that the four components measured were based on readiness $<50.0 \%$ (range $36.78 \%-45.31 \%$ ). There is still an opportunity to increase its readiness in terms of the category of less ready with a range of $35.89 \%-51.01 \%$ and not ready with a range of $9.48 \%-25.74 \%$. The aspect of teacher readiness that shows the highest level of success is the $\mathrm{CC}$ and $\mathrm{BC}$ analysis of $45.31 \%$, even though the other components obtained the category $<45.31 \%$. Vocational teachers after the $\mathrm{CC}$ and $\mathrm{BC}$ process must be able to pour these competencies into the learning program. A decrease in yield has occurred from $45.31 \%$ to $38.37 \%$. The results of the FGD have been evaluated from various opinions of vocational teachers and viceprincipals led by the education office: 
"Our difficulty is that teachers understand operational verbs (KKO) and distinguish the choice of words used. Furthermore, pouring it into annual and semester programs is not easy. We often experience loose concepts, we even realize before the last weeks of exams, and often there are still some competencies that have not been delivered." (TG)

The evaluation of the group of principals' leaders delivered by the vice-principal in the field of curriculum is:

"We have provided various training and strengthening understanding before new learning begins, but it is not easy. Teachers have been instructed to form subject groups and join MGMP among subject teachers, but again the results in the learning tools are still the same as last year and some of our teachers find the collection always at the end of time. Even when supervisors question the content of learning tools from the preparation of learning programs, no systematic results are obtained. Especially teachers who implemented the 2004 curriculum to be directly involved in the 2013 curriculum, took a long time." (CG)

It is clear that KKOs are of concern to be explained in detail to vocational teachers. In addition, the deputy headmaster and supervisors must be more concerned with senior teachers, requiring intensive guidance. However, teacher readiness occurs an insignificant increase from learning programs for learning tools. The reason is that it is assumed that vocational teachers prepare lesson plans more than learning programs or that most of them imitate learning tools among cognate subject teachers. But the results have no significant effect.

Difficulties are also experienced in the evaluation aspects of learning with the lowest acquisition of other aspects. The researcher reviewed that the 2013 curriculum recommended levels of learning objectives and learning assessment. The habit of vocational teachers in making questions is to provide taxonomies at the LOTS level and not to be interpreted according to the choice of words based on KKO. Better processes and supervision are needed to improve the readiness of vocational teachers in developing learning tools.

The group of vice principals in the field of curriculum argues that teachers of the 2004 curriculum (KBK) experienced serious difficulties in preparing learning tools, in accordance with the opinions [42, 43]. Those results of the category predominantly fall into the category of less ready and not ready. A strategy that is not limited to training and assistance is needed. However, the 2013 curriculum is identical with the learning concept that leads to technology $[7,44,45]$. That's far more difficult.

\subsection{Teacher's ability to make a lesson plan}

Vocational teacher pedagogical competence is the ability to lesson planning in class and workshop [46], effectively [47]. The ability to make lesson plans means that vocational teachers have mastered the principles of the 2013 revised curriculum. Lesson planning is a way for teachers to achieve goals [48], namely the competencies of students. Each vocational teacher has a different way; however, the principles of systematic writing must be in accordance with the rules that have been used as a standard reference.

Systematic development of lesson plans consists of three types including: 1) Ministry of Education and Culture Regulation (Permendikbud) No. 103 of 2014; 2) Permendikbud No. 22 of 2016; and 3) Combination No. 103 of 2014 and No. 22 of 2016. Vocational teachers are given the freedom to choose the lesson planning component. The researcher explains that the learning plan is a follow-up to the learning program. Thus, the results of the survey focused on four important variables of the learning device components, including: 1) Instructional program; 2) Instruction plan; 3) Instructional media; and 4) Assessment and others. A strong consideration in the selection of variables is the suitability of the characteristics of the 2013 curriculum. The lesson plans prepared by vocational teachers are then assessed based on indicators of learning tools. The assessment results are shown in Table 4. 
Table 4. Results of quality analysis of vocational teacher learning plans

\begin{tabular}{|c|c|c|c|c|}
\hline Aspect of assessment of learning device components & Port. & Score (Max) & Score (Real) & $(\%)$ \\
\hline \multicolumn{5}{|l|}{ Instructional program } \\
\hline 1) Compatibility of curriculum structure & 2 & 1914 & 1467 & 76.65 \\
\hline 2) Time distribution conformity & 2 & 1914 & 1499 & 78.32 \\
\hline \multicolumn{5}{|l|}{ Instructional plan } \\
\hline 1) Completeness of components & 2 & 1914 & 1667 & 87.10 \\
\hline 2) Inter-component compliant & 2 & 1914 & 1478 & 77.22 \\
\hline Compatibility of competencies and competency achievement indicators & 2 & 1914 & 1535 & 80.20 \\
\hline 4) Learning objectives conformity & 2 & 1914 & 1555 & 81.24 \\
\hline 5) Material selection and organization & 2 & 1914 & 1357 & 70.90 \\
\hline 6) Suitability of learning activities & 2 & 1914 & 1333 & 69.64 \\
\hline 7) Learning methods Selection & 2 & 1914 & 1435 & 74.97 \\
\hline 8) Media, tools and learning resources selection & 2 & 1914 & 1449 & 75.71 \\
\hline 9) Feasibility of learning outcomes evaluation & 2 & 1914 & 1533 & 80.09 \\
\hline \multicolumn{5}{|l|}{ Instructional media } \\
\hline 1) Variation and suitability & 2 & 1914 & 1237 & 64.63 \\
\hline 2) Innovation and novelty & 2 & 1914 & 1414 & 73.88 \\
\hline \multicolumn{5}{|l|}{ Assessment and others } \\
\hline 1) Knowledge, Skills and Attitude Assessment (KSA) & 1 & 957 & 667 & 69.70 \\
\hline 2) Scientific Approach Integration $(5 \mathrm{M}) /(\mathrm{OACAC})$ & 2 & 1914 & 1323 & 69.12 \\
\hline
\end{tabular}

Table 4 explains that the average instructional program component is $77.5 \%$; instructional plan of $77.5 \%$; instructional media by $69.3 \%$; and the assessment and others $69.4 \%$. The quality of the preparation of learning tools as a whole is in the "quality" category (71-85\%) although there are two aspects in the "Moderate" category (56-70\%), namely instructional media and assessment, and others. The 2013 curriculum which is identically close to technology [44], requires time for a number of teachers to use good and effective media. A number of vocational teachers as practitioners stated that:

"Vocational learning is always closer to practice in workshops. In general, we open a short learning, then the student completes the work. This makes it difficult for us as 'vocational teachers' if we have to use a number of technologies involved in the practicum process. In addition, the availability of technology-based practice facilities such as those in the industry is not ready to be operated. Frankly, we are worried that damage will occur, because there is no prior training. As for assessment, it's a practical evaluation. Especially now that attitudes have been assessed, yes..., This is new for us to observe student activities. But with their habits, we know how their values are appropriate." (GG)

Things that need to be improved are the habits and mindset of vocational teachers that technology facilitates understanding and skills that must be delivered for quality learning. Hard skills are important to convey and transform through learning experiences, however soft skills have a more role to adapt to changes and the needs of lifelong learning [26, 49].

Assessment aspects and other aspects need to be realized by vocational teachers that competence is an integration of three aspects, namely knowledge, skills and attitudes [50-52]. One aspect of supporting competencies is not fulfilled so students in doing work cannot be declared as competent students. Vocational teachers must teach and measure every aspect students get during practice. But the practice is the application of a certain amount of knowledge and attitudes that are allowed. Also, mistakes in attitude during training result in more dangerous risks. Researcher's analysis that vocational teachers need similar CBT training. The aim is none other than improving the ability of methodology and technical expertise [53, 54], to be simulated to students directly and not limited to instruction.

\subsection{Overall difficulties}

Based on the results of the readiness and ability of vocational teachers in developing learning tools, it was found several notes on FGD results on several components that were considered difficult. This statement is very scientific, especially the problem of media, methods and assessments. The 2013 curriculum as a development curriculum certainly has a different way from the previous curriculum. The concept that was considered new, gave rise to diverse perceptions of vocational teachers. The researcher collects a number of opinions from the respondents shown in Table 5. 
Table 5. Teachers overall difficulties from revision 2013 curriculum standpoint

\begin{tabular}{lcc}
\multicolumn{1}{c}{ Components of learning devices with difficulty levels } & $\mathrm{F}$ & $(\%)$ \\
\hline Development of authentic assessment & 567 & 40.0 \\
Selection of suitable learning methods & 525 & 37.5 \\
Appropriate literacy approach & 497 & 35.5 \\
Lesson plans & 497 & 35.5 \\
Understanding of learning programs based on CC/BC and learning objectives & 350 & 25.0 \\
Others & 119 & 8.5 \\
\hline
\end{tabular}

A total of four important components for vocational teachers with very difficult perceptions $(<40 \%)$ are authentic assessment (40\%), learning method (37.5\%); literacy approach (35.5\%); and lesson plans $(35.5 \%)$. Authentic assessment is considered difficult if each learning must assess three aspects at once, namely knowledge, skills, and attitudes. Competence is a combination of the three aspects, so competencies are adjusted to the objectives of learning. The use of methods is felt to be difficult if learning is carried out in theory and practice differently. Teachers' understanding is still limited to how the method can work well with the concepts of theory and practice. So, in the completion of CC and BC is not limited to one learning method. The literacy approach is considered difficult because of limited infrastructure and poor literacy understanding. The researcher is of the opinion that vocational teachers need discussion between MGMPs to solve problems or concepts of learning in the same subject.

\subsection{Lesson plan quality}

Survey data describe that the readiness of vocational teachers for the preparation of learning tools and the quality of learning tools based on the characteristics of the 2013 curriculum, as a whole are categorized as "not ready" and "moderate". The researcher concludes that the implementation of training and mentoring as well as the supervision process are not yet on target. Then the results of surveys become recommendations that vocational teachers need training for practitioners directly. In its implementation, needs must be distinguished based on the strong experience of teachers in implementing the 2013 curriculum. Because, teachers with 2004 curriculum experience need detailed assistance. However, the key to success by the readiness and quality of vocational teacher learning tools is reflected in how strong the teacher's understanding. In line with the research conducted by Chan [55], the development of teacher understanding is an important factor in curriculum application. Not all teachers are on the same category level, apart from that all the functions of implementing the 2013 curriculum have the same goal.

The unpreparedness of supporting facilities is important to consider such as books for students and teachers in vocational. The researcher believes that this is one of the causes of the low success in implementing the 2013 curriculum $[40,56]$. The researcher believes that the role of school leaders and the education department is an important element in supporting success. Especially providing motivation and describing the conditions of the vocational schools during the implementation of the 2013 curriculum. In addition, vocational teachers must build literacy, discussion and sharing from the implementation which is considered difficult in MGMP institutions. Vocational teachers can evaluate the readiness and the improvement of the quality of learning tools for cognate or level teachers. An important role also occurs in school supervisors were one of the tasks is validating the lesson plans of vocational teachers. This role should be reported from weaknesses and recommendations that must be improved, not only limited to carrying out administrative characteristics.

The success of the quality of learning tools that have been prepared is also supported by instructional media including the integration of ICT in the learning process. A number of respondents describe that there are many schools with ICT availability of $69.3 \%$ in the "moderate" category. However, there will be a shift that learning is more about utilizing the ICT function. So the management of vocational schools began to plan ICT needs and improve ICT based learning. This will be an obstacle for vocational teachers in certain age groups that are difficult to follow technological developments. Whereas the ability to use ICT based learning media increases the quality of the learning process [57].

The quality of vocational teacher learning tools for assessment and activities of the OACAC is $69.4 \%$ in the "moderate" category. Part of vocational teachers show the ambiguity between competence and assessment. Even the use of the KKO and assessment indicators used have not yet been measured [58]. However, knowledge, skills and attitude competencies must measure learning objectives. The level of competency measurement is adjusted to class level and the increase is emphasized at the dominating HOTS level. 


\section{CONCLUSION}

The readiness and quality of learning tools compiled by vocational teachers are: 1) The level of readiness of vocational teachers in the preparation of learning tools is reviewed based on CC and BC analysis, preparation of annual and semester programs, preparation of lesson plans, evaluation of learning in the "Ready" category less than $45.37 \%$. "Less Ready" overall is below 51.07\%, and "Not Ready" overall is $25.74 \%$. The readiness results recommend that teachers with "Less Ready" and "Not Ready" readiness need specific training and mentoring; 2) The quality of learning tools that have been prepared is based on instructional program, instruction plans, instructional media, and assessments and others developed from SLPAI in the "Quality" category for instructional programs and plans while "Moderate" for instructional media and assessments. These results indicate that the teacher as a whole has not mastered the preparation of learning tools according to the characteristics of the 2013 curriculum; and 3) All components of the learning tool, vocational teachers find it difficult to authentic assessment, use of methods, literacy approaches and lesson planning.

The curriculum practitioners in 2013 consisted of various ages, school readiness and school management who were highly committed to the success of learning. All 2013 curriculum practitioners must have a high awareness of every action in implementing it. Some training and assistance emphasize more on the needs and who the targets are. It is not recommended that vocational teachers be considered to have the same perception and produce the same achievements.

\section{REFERENCES}

[1] N. Norris, Curriculum and the Teacher: 35 Years, of the Cambridge Journal of Education. Routledge, 2014.

[2] S. Nunalall, "The effect of continuous curriculum policy changes on the professional lives of foundation phase teachers in post-apartheid South Africa," Thesis, Teacher Education and Professional Development at the University of KwaZulu Natal: Edgewood Campus: Durban, 2012.

[3] Z. Li, Z. Yan, and Z. Yu, "A Study on Problems and Strategies of Curriculum Resources Development and Utilization by Teachers in Rural Junior Middle School: A Case Study of a County of Sichuan Province in China," Cross-Cultural Communication, vol. 10, no. 5, pp. 154-158, 2014.

[4] P. F. Oliva, Developing the Curriculum. Allyn and Bacon, 2005.

[5] L. Aprillianti, "Comparison between Concept of Evaluation on KTSP Curriculum and 2013 Curriculum," UHAMKA International Conference on ELT and CALL (UICELL), 2018, pp. 95-109.

[6] N. H. Ulya, "The Effects of the Implementation of 2013 Curriculum to Students' English Learning Achievement at SMAN 1 Alla' Enrekang,” Engl. Teach. Learn. Res. J. (ETERNAL), vol. 1, no. 1, pp. 145-166, 2015.

[7] N. Noviawati, "The Implementation of 2013 Curriculum in English Teaching Learning at Man 1 Pekalongan," Indonesian Journal of English Teaching, vol. 6, no. 2, pp. 218-228, 2017.

[8] N. Aceska, "New Science Curriculum Based on Inquiry Based Learning - A Model of Modern Educational System in Republic of Macedonia," Journal of Education in Science Environment and Health, vol. 2, no. 1, pp. 1-12, 2020.

[9] S. H. Hasan, "History Education in Curriculum 2013: A New Approach to Teaching History," Historia Jurnal Pendidik Dan Peneliti Sejarah, vol. 14, no. 1, pp. 163-178, 2013.

[10] P. Suparno, "Curriculum as a subject of experiment," The Jakarta Post, 2020. [Online]. Available: https://www.thejakartapost.com/news/2014/12/18/curriculum-a-subject-experiment.html.

[11] S. Suyanto, "A reflection on the implementation of a new curriculum in Indonesia: A crucial problem on school readiness," AIP Conference Proceedings, vol. 1868, no. 1, 2017, doi: 10.1063/1.4995218.

[12] S. Blackley, Y. Rahmawati, E. Fitriani, R. Sheffield, and R. Koul, "Using a Makerspace approach to engage Indonesian primary students with STEM," Issues in Educational Research, vol. 28, no. 1, pp. 18-52, 2018.

[13] C. R. Prihantoro, "The perspective of curriculum in Indonesia on environmental education," International Journal of Research Studies in Education, vol. 4, no. 1, pp. 77-83, 2014.

[14] Z. Ayvaz-Tuncel and İ. Tuncel, "Good teacher perceptions of students attending the pedagogical formation certificate program," International Journal of Evaluation and Research in Education (IJERE), vol. 8, no. 1, pp. 165-172, 2019, doi: 10.11591/ijere.v8i1.17093.

[15] H. Ujir, S. F. Salleh, A. S. W. Marzuki, H. F. Hashim, and A. A. Alias, "Teaching workload in 21 st century higher education learning setting," International Journal of Evaluation and Research in Education (IJERE), vol. 9, no. 1, pp. 221-227, 2020, doi: 10.11591/ijere.v9i1.20419.

[16] C. Wacker and L. Olson, "How Educators' Perspectives Shape Student Success," Teaching Channel, p. 30, 2019.

[17] D. Lynch and R. Smith, "Designing the Classroom Curriculum," 2011. [Online]. Available: Lulu.com.

[18] H. Retnawati, et al., "Vocational High School Teachers' Difficulties in Implementing the Assessment in Curriculum 2013 in Yogyakarta Province of Indonesia," Int. J. Instr., vol. 9, no. 1, pp. 33-48, 2016.

[19] U. Kusmawan, et al., "Emerging Perspectives and Trends in Innovative Technology for Quality Education 4.0," Proc. 1st Int. Conf. on Innov. in Educ. and Pedagogy (ICIEP 2019), Routledge, 2020, p. 274.

[20] I. Gunawan, "Indonesian Curriculum 2013: Instructional Management, Obstacles Faced by Teachers in Implementation and the Way Forward," Proceedings of the 3rd International Conference on Education and Training (ICET 2017), 2017, doi: 10.2991/icet-17.2017.9. 
[21] T. Fujii, "Designing and Adapting Tasks in Lesson Planning: A Critical Process of Lesson Study," ZDM Int. J. Math. Educ., vol. 48, no. 4, pp. 411-423, 2016.

[22] B. Piper, Y. Sitabkhan, J. Mejia, and K. Betts, Effectiveness of Teachers' Guides in the Global South: Scripting, Learning Outcomes, and Classroom Utilization. RTI Press, 2018.

[23] D. Yusnida, A. Muslem, and A. Manan, "A Study of Teaching Listening," English Education Journal EEJ, vol. 8, no. 4, pp. 439-456, 2017.

[24] Z. Arifin, M. Nurtanto, A. Priatna, N. Kholifah, an M. Fawaid, "Technology Andragogy Work Content Knowledge Model as a New Framework in Vocational Education: Revised Technology Pedagogy Content Knowledge Model," TEM J., vol. 9, no. 2, pp. 786-791, 2020.

[25] Z. Arifin, M. Nurtanto, W. Warju, R. Rabiman, and N. Kholifah, "The TAWOCK Conceptual Model for Content Knowledge for Professional Teaching in Vocational Education," International Journal of Evaluation and Research in Education (IJERE), vol. 9, no. 3, pp. 697-703, 2020, doi: 10.11591/ijere.v9i3.20561.

[26] B. Hurst, R. Wallace, and S. B. Nixon, "The Impact of Social Interaction on Student Learning," Reading Horizons: A Journal of Literacy and Language Arts, vol. 52, no. 4, pp. 375-398, 2013.

[27] J. M. Harackiewicz, J. L. Smith, and S. J. Priniski, "Interest Matters: The Importance of Promoting Interest in Education," Policy Insights from the Behavioral and Brain Sciences, vol. 3, no. 2, pp. 220-227, 2016.

[28] H. Timperley, Teacher professional learning and development: best evidence synthesis iteration (BES). Wellington (New Zealand): Ministry of Education, 2007.

[29] C. Girvan, C. Conneely, and B. Tangney, "Extending experiential learning in teacher professional development," Teaching and Teacher Education, vol. 58, pp. 129-139, 2005, doi: 10.1016/j.tate.2016.04.009.

[30] M. Palobo, M. Sianturi, I. Marlissa, R. Purwanty, O. Dadi, and A. Saparuddin, "Analysis of Teachers' Difficulties on Developing Curriculum 2013 Lesson Plans," Proceedings of the 1st International Conference on Social Sciences (ICSS 2018), 2018, doi: 10.2991/icss-18.2018.278.

[31] S. Asari, N. Fauziyah, and S. Uchtiawati, "Improving Teacher Pedagogic Competences in Remote Areas through Lesson Study Activity," International Journal of Education and Literacy Studies, vol. 6, no. 2, pp. 53-62, 2018.

[32] F. A. Ningtiyas and Jailani, "Does Teacher's Training Affect the Pedagogical Competence of Mathematics Teachers?” Journal of Physics: Conference Series, vol. 1097, 2018, doi: 10.1088/1742-6596/1097/1/012106.

[33] M. H. Rahman, "Professional Competence, Pedagogical Competence and the Performance of Junior High School of Science Teachers," Journal of Education and Practice, vol. 5, no. 9, p. 75, 2014.

[34] A. Hakim, "Contribution of Competence Teacher (Pedagogical, Personality, Professional Competence and Social) On the Performance of Learning," The International Journal of Engineering and Science (IJES), vol. 4, no. 2, pp. 1-12, 2015.

[35] A. Saeroji, A. Slamet, and M. Khafid, "Scientific Learning Approach on Subject Material Computer Application for Financial Administration," Jorunal of Economic Education, vol. 7, no. 1, pp. 10-17, 2017.

[36] I. Nurhikmayati and I. Nurhikmayati, "Scientific Learning to Improve Critical Thinking Ability," EduMa: Mathematics Education Learning and Teaching, vol. 7, no. 2, pp. 1-10, 2018.

[37] S. Suyanto, "The Implementation of the Scientific Approach through 5Ms of the New Curriculum of 2013 in Indonesia," Jurnal Cakrawala Pendidikan, vol. 37, no. 1, pp. 22-29, 2018.

[38] S. Reis, "Curriculum reform: Why? What? How? And how will we know it works?" Israel Journal of Health Policy Research, vol. 7, no. 30, 2018, doi: 10.1186/s13584-018-0221-4.

[39] L. M. Rea and R. A. Parker, Designing and Conducting Survey Research: A Comprehensive Guide. John Wiley \& Sons, 2014.

[40] C. L. Jacobs, S. N. Martin, and T. C. Otieno, "A Science Lesson Plan Analysis Instrument for Formative and Summative Program Evaluation of a Teacher Education Program," Science Education, vol. 92, no. 6, pp. 1096-1126, 2008.

[41] S. Arikunto, Research procedure: A practical approach (in Bahasa). Jakarta: Rineka Cipta, 2011. [Online]. Available: https://opac.perpusnas.go.id/DetailOpac.aspx?id=217760.

[42] T. J. Swim, Infants and Toddlers: Curriculum and Teaching. Cengage Learning, 2013.

[43] E. A. Nevenglosky, C. Cale, and S. P. Aguilar, "Barriers to effective curriculum implementation," Research in Higher Education Journal, vol. 36, pp. 1-31, 2019.

[44] A. Jaedun and V. L. Hariyanto, "An Evaluation of The Implementation of Curriculum 2013 at The Building Construction Department of Vocational High Schools in Yogyakarta," Journal of Education, vol. 7, no. 1, pp. 14-22, 2014.

[45] R. Rasmitadila, et al., "The Perceptions of Primary School Teachers of Online Learning during the COVID-19 Pandemic Period: A Case Study in Indonesia," Journal of Ethnic and Cultural Studies, vol. 7, no. 2, pp. 90-109, 2020, doi: $10.29333 /$ ejecs/388.

[46] R. V. Brittin, "Preservice and Experienced Teachers' Lesson Plans for Beginning Instrumentalists:" Journal of Research in Music Education, vol. 53, no. 1, pp. 26-39, 2016.

[47] L. Rusznyak and E. Walton, "Lesson planning guidelines for student teachers: A scaffold for the development of pedagogical content knowledge," Education as Change, vol. 15, no. 2, pp. 271-285, 2011.

[48] E. Vdovina and L. C. Gaibisso, "Developing Critical Thinking in the English Language classroom: A Lesson Plan," English Language Teachers' Association (ELTA SERBIA), vol. 1, no. 1, pp. 54-68, 2013.

[49] A. Ismail, et al., "Effectiveness of Entrepreneurship Programmes in Developing Entrepreneurship Skills towards Quality TVET Graduates," Journal of Technical Education and Training, vol. 11, no. 1, pp. 081-086, 2019, doi: 10.30880/jtet.2019.11.01.010.

[50] E. H. Y. Koh, Risk Management Competency Development in Banks: An Integrated Approach. Palgrave Pivot, 2019. 
[51] D. Linda and L. Miltiadis, Learning Strategies and Constructionism in Modern Education Settings. IGI Global, 2018.

[52] A. Masek, "An Appropriate Technique of Facilitation Using Students' Participation Level Measurement in the PBL Environment," International Journal of Engineering Education, vol. 32, no. 1(B), pp. 402-408, 2016.

[53] M. Nurtanto, Z. Arifin, H. Sofyan, W. Warju, and S. Nurhaji, "Development of Model for Professional Competency Assessment (PCA) in Vocational Education: Study of the Engine Tune-Up Injection System Assessment Scheme," J. Tech. Educ. Train., vol. 12, no. 2, pp. 34-45, 2020.

[54] M. Nurtanto, H. Sofyan, P. Pardjono, and S. Suyitno, "Development model for competency improvement and national vocational qualification support frames in automotive technology," International Journal of Educational Research (IJERE), vol. 9, no. 1, pp. 168-176, 2020, doi: 10.11591/ijere.v9i1.20447.

[55] J. K.-S. Chan, "Teachers' responses to curriculum policy implementation: colonial constraints for curriculum reform," Educational Research for Policy and Practice, vol. 9, no. 2, pp. 93-106, 2010.

[56] S. Sentance and A. Csizmadia, "Computing in the curriculum: Challenges and strategies from a teacher's perspective," Education and Information Technologies, vol. 22, no. 2, pp. 469-495, 2017.

[57] R. Rabiman, M. Nurtanto, and N. Kholifah, "Design and development E-learning system by learning management system (Lms) in vocational education," International Journal of Scientific \& Technology Research, vol. 9, no. 1, pp. 1059-1063, 2020.

[58] C. J. Stanny, "Reevaluating Bloom's Taxonomy: What Measurable Verbs Can and Cannot Say about Student Learning," Education Sciences, vol. 6, no. 37, pp. 1-12, 2016. 